\title{
Volcano gets choke chains to slow mud
}

Indonesian geophysicists hope to stem the flow of a destructive mud volcano on East Java by dropping chains of concrete balls into its mouth.

The muderuption began on 29 May last year in the middle of a rice paddy in the village of Porong, 30 kilometres south of Surabaya, the provincial capital. Since then, the volcano has spewed out up to 126,000 cubic metres of mud a day, flooding an area of more than 4 square kilometres.

Some 10,000 people have been left homeless and 20 factories have closed. Another 200,000 homes could be at risk if the mudflow combines with the rainy season - which has just begun - and weakening dams to flood more land Attempts to alleviate the problem by drilling relief wells or channelling the mud into a nearby river have so far failed.

Last week, the government team tackling the disaster approved a plan that will use 1,000 steel chains to try to slow the flow of mud. Each chain is 1.5 metres long and links together four concrete balls - two that are 40 centimetres across and two that are 20 centimetres across. Each ball and chain set will weigh about 300 kilograms. The balls themselves

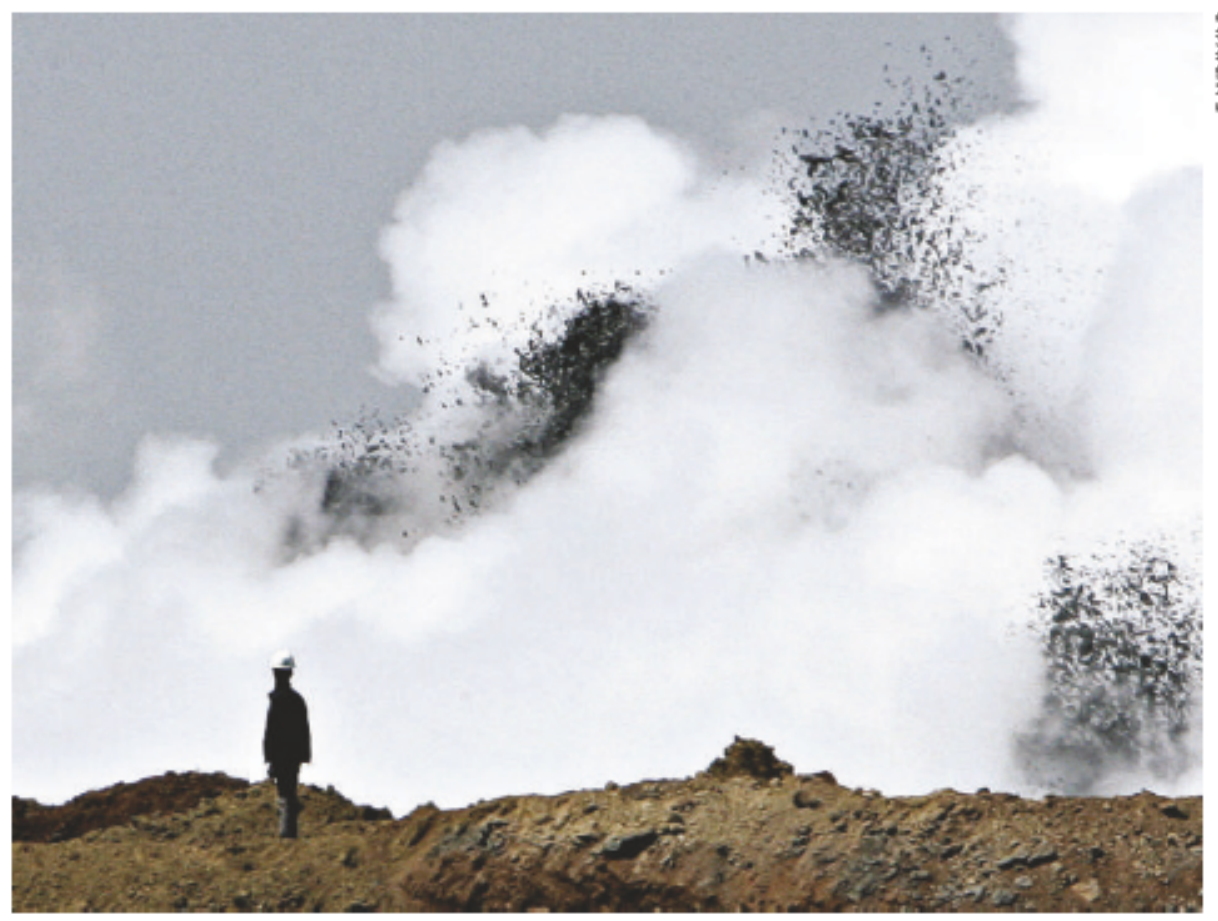

Can geophysicists calm the mud volcano that has been er upting for eight months in East Java? will be modified to maximize their friction with the mud.

The team will start off slowly, dropping five chains into the volcano's mouth on the first day - possibly as early as this week - and ten on the second, before hitting a high of up to 50 per day until all of them are used.

The scheme was dreamt up by three geophysicists at the Bandung Institute of Technology: Bagus Nurhandoko, Satria Bijaksana and Umar Fauzi. According to Basuki Hadimuljono, head of the national team managing the disaster, the

the foundations of a bridge that will span the crater and, with the help of a pulley system, will be used for dropping in the chains.

The chains will sink into the conduit that has been feeding the hot mud to the surface, Fauzi explains. "We are aiming to get them to go 100 metres down, but the deeper the better," he says. The goal is to make the channel smaller - not plugging it altogether but, according to a model built by the team, narrowing it enough to slow the mud's rise and so decrease its flow rate by up to three-quarters. Forced to go around the project will have a budget of 4 billion rupiah (US $\$ 440,000$ ) paid for by PT Lapindo Brantas, the oil drilling company that some locals blame for the disaster.

Bijaksana says that the mudflow calls for an unprecedented solution. "At first we thought it was a common problem in oil exploration, but after a few months we realized this was not a standard situation," he notes.

On 22 January, in a smoky room at the disaster management team's Surabaya headquarters, the geophysicists met with scientists and engineers from the government and the oil company to work out the details of the plan. The next day, Bijaksana and Fauzi were crawling up the side of the volcano to map out plans for predict that the mud would probably exit at the other holes, or farther along," says Swarbrick. This would just transfer the problem to somewhere else. "The mud will find another way out," he says.

Confident in the face of such criticism, Bijaksana and his colleagues admit that their plan might sound improbable at first. "It took a few months to settle down and make peace with ourselves," he says. But the trio used a simple analogy to sell the project to the government. They cut two holes in the bottom of a plastic bottle and filled it with water. Covering one hole, they showed that the flow rate from the other is unaffected - but the overall rate at which the water leaves the bottle decreases. Likewise, with the volcano, they believe that the volume coming out is directly proportional to the size of the neck of the conduit bringing the mud to the surface.

Bijaksana says there are still uncertainties - the exact flow rate of the mud, for example, and the shape of the crater - that could affect the project's success. He hopes that instruments now being laid over the crater will provide some more information, and adds that he isn't worried about the uncertainty. ${ }^{\text {"People }}$ all around here are living in uncertainty, he points out.

David Cyranoski 